\title{
An investigation of Pierre de Wet's role in the Afrikaans film industry using social network analysis (SNA)
}

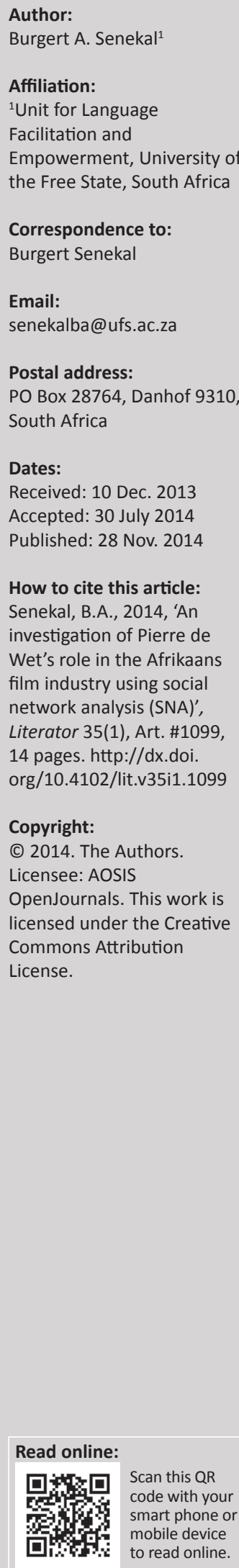

Although the film industry - like the literary system - can be described as a cultural system or field, systems theory remains largely unexplored in South African film studies, as does the more recent network theory. Systems theory and network theory both emphasise the relationships of an entity within a larger context, arguing that an entity should be studied within the relationships in which it functions. Recently, researchers have suggested that network theory can be integrated with polysystem theory to study the interactions between entities in the literary system. This article illustrates the potential of using social network analysis (SNA) as an investigative tool to identify and describe the role of an entity within the context of the film industry by focusing on one of the seminal Afrikaans film makers: Pierre de Wet. Pierre de Wet has been intricately involved with the beginnings of the Afrikaans film industry, collaborating with, amongst others, some of the most prolific film editors, producers, cinematographers and music composers. His major collaborators are highlighted as well as his central position in the Afrikaans film industry, taking into account the entire Afrikaans film industry from its origin to the contemporary period. The article also makes suggestions for further research.

'n Ondersoek na Pierre de Wet se rol in die Afrikaanse rolprentbedryf deur middel van sosiale-netwerk-analise (SNA). Hoewel die filmindustrie - soos die literêre sisteem beskryf kan word as 'n kulturele sisteem of -veld, bly die sisteemteorie grootliks onverken in Suid-Afrikaanse filmstudies, en so ook die meer onlangse netwerkteorie. Die sisteem- en netwerkteorie beklemtoon beide die verhoudings van 'n entiteit binne 'n groter konteks, met die argument dat 'n entiteit bestudeer moet word binne die netwerk van verhoudings waarbinne hy funksioneer. Onlangs het Senekal voorgestel dat die netwerkteorie geïntegreer kan word met die polisisteemteorie om die interaksies tussen entiteite in die literêre sisteem te bestudeer. Hierdie artikel illustreer die potensiaal van sosiale-netwerk-analise (SNA) as 'n ondersoekende instrument deur die rol van 'n entiteit binne die konteks van die filmbedryf te identifiseer en te beskryf. Die fokus val op een van die seminale Afrikaanse filmmakers: Pierre de Wet. Daar word aangetoon in hoe 'n mate Pierre de Wet betrokke was by die begin van die Afrikaanse rolprentbedryf, onder andere saamgewerk het met 'n groot aantal van die mees produktiewe filmredakteurs, produsente, kinematograwe, en musiekkomponiste. Sy belangrikste medewerkers word uitgelig, sowel as sy sentrale posisie in die Afrikaanse rolprentbedryf, met inagneming van die hele Afrikaanse rolprentbedryf, van aanvang tot hede. Die artikel maak ook voorstelle vir verdere navorsing.

\section{Introduction}

The social environment is a complex system (Barabási 2009:413; Mitchell 2006:1195) in which the interactions between millions of role players result in the emergence of a higher function than the total of individual contributions. Complex systems are 'composed of populations of adaptive agents whose interactions result in complex non-linear dynamics, the results of which are emergent system phenomena' (Brownlee 2007:1). Most of mankind's environment can be described as a complex system, including systems such as the Internet, the World Wide Web, ecosystems, weather systems and indeed living organisms themselves. In particular, the cultural environment is often described as a system; Senekal (1987:44) for instance writes that 'kultuur is 'n web, nie 'n stukkie drukwerk in isolasie nie [culture is a web, not a piece of printed material in isolation]' (see also Senekal 2013a; Viljoen 1986).

Complex systems can be approached in the same way as complex networks. Although there are differences between systems theory and network theory, in essence, both focus on the relationships between entities in a system or network and both theoretical paradigms argue that the total functionality of a system is the result of the interactions (relationships) between 
entities. Network theory has the advantage that it allows for the visual representation of a system, as well as mathematical formulae for calculating different aspects of centrality, as discussed by Senekal (2013a). In addition, the network approach functions as an investigative tool, helping the researcher to identify connections between entities through visual representations, which is one of the reasons why social network analysis (SNA, an application of network theory to social networks) has been applied to terrorist and criminal networks. Visual representations aid understanding and support the communication of findings (Brandes, Freeman \& Wagner 2013:807). Network theory is however more than simply an investigative tool; it offers a theoretical paradigm as well (see e.g. Senekal 2013a). ${ }^{1}$

The film industry can be perceived as a system or network, in which different entities, including actors, producers, editors, production companies, distribution companies, funding agencies, directors, critics, the public and film historians, interact. As with any system, the whole is much more than the sum of its parts: of course the film industry as a whole is much more than the work of a single director.

In this article, the Afrikaans film industry is therefore seen as a social system that - along with music, literature, theatre, television, and so on - forms part of the larger cultural networks of South African society. Against the backdrop of network theory and systems theory, the article considers the professional relationships of Pierre de Wet, where professional relationships are defined as credited collaborations on films. Pierre de Wet is often referred to as 'the father of the Afrikaans film industry' (e.g. by Britz 1990:3; Van der Westhuizen 2012), which illustrates that some commentators recognise his contribution as important to the industry as a whole. Using SNA tools, this article follows Senekal and Stemmet (2014) in describing De Wet's context in terms of the people and companies he worked with, placing him in the context of the entire Afrikaans film industry. Although numerous studies have been published on the South African film industry (see e.g. Botha 2006a, 2012; Blignaut \& Botha 1992; Gutsche 1972; Le Roux \& Fourie 1982; Tomaselli 1988), Pierre de Wet's role in the Afrikaans film industry in terms of connections has never been studied using SNA. As such, the article does not attempt to discuss De Wet's individual works, as done by Gutsche (1972), Tomaselli (1988) and Botha (2006b, 2012), but rather to use SNA to highlight some of De Wet's principal collaborators, and to identify De Wet's structural position in the industry.

To facilitate such an investigation, a database was compiled that includes entities such as films, directors, film editors, producers, writers, cinematographers, music composers, production companies and distribution companies that were involved in the Afrikaans film industry, spanning nearly a century (from 1916-2013). Firstly, the work of Le Roux and Fourie (1982) was used as a source of data

1.To avoid repetition, and to allow more space for a discussion of the application, this section on the theoretical background is necessarily brief. See Senekal (2013a) for more detailed discussion of network theory and systems theory. on this industry, which allowed for an authoritative starting point. Details were added using the Internet Movie Database (http://www.imdb.com), which offers a comprehensive (albeit incomplete) overview of the entire global film industry, including the Afrikaans film industry. The relationships between the abovementioned entities were then plotted using SNA software, Sentinel Visualizer. Although the compiled database may not be complete, it is comprehensive, which is important when placing such a prolific filmmaker in the proper context: connections in a social network reach far and wide and all have an impact on a specific entity's role. As such, this article attempts a radical contextualisation of one of the Afrikaans film industry's key filmmakers.

\section{Overview of Pierre de Wet's career}

Although only his Afrikaans films are considered here, and his role as actor is not considered in this network, Pierre de Wet was intimately involved with the beginnings of the film industry in South Africa in general. He starred in the first 'talkies': Sarie Marais (1931) and Moedertjie (1931) (Botha 2006a; Hechter 2010) - both Afrikaans films - and his debut as director, Pinkie se erfenis (1946), 'kan as die geboorte van die Afrikaanse rolprentbedryf beskou word [can be seen as the birth of the Afrikaans film industry]' (Van der Westhuizen 2012). His film Kom saam vanaand! (1949) was also the first Afrikaans musical; between 1946 and 1961, Pierre de Wet worked on 18 Afrikaans films. Of these, he directed 17 and wrote 15, whilst bringing together some of the most prolific people in the Afrikaans film industry. De Wet directed the following films:

1. Pinkie se Erfenis [Pinkie's Inheritance] (1946) (drama)

2. Geboortegrond [Land of Birth] (1946) (drama)

3. Simon Beyers (1947) (drama)

4. Die Kaskenades van Dr. Kwak [The Adventures of Dr Kwak] (1948) (comedy)

5. Kom saam Vanaand [Come with me Tonight] (1949) (musical)

6. Hier's ons Weer [Here we are Again] (1950) (comedy)

7. Alles sal Regkom [Everything Will Turn Out Fine] (1951) (comedy)

8. Altyd in my Drome [Always in My Dreams] (1952) (musical)

9. Vadertjie Langbeen [Daddy Long-Legs] ${ }^{2}$ (1954) (drama)

10. 'n Plan is 'n Boerdery [Nothing Like Ideas] (1954) (comedy)

11. Matieland (1955) (comedy)

12. Dis Lekker om te Lewe [It's Good to be Alive] (1957) (comedy)

13. Fratse in die Vloot [Buffoonery in the Navy] (1958) (comedy)

14. Nooi van my Hart [Girl of my Heart] (1959) (musical)

15. Piet se Tante [Piet's Aunt] (1959) (comedy)

16. Oupa en die Plaasnooientjie [Grandpa and the Farm Girl] (1960) (comedy)

17. En die Vonke Spat [And the Sparks Fly] (1961) (comedy)

2.This film was based on an American film, Daddy long-legs (1919), written by Jean Webster and directed by Marshall Neilan. 
Whilst the majority of these films were comedies (10 out of 17), De Wet obviously made dramas (four) and was involved with musicals (three) as well. From this list it is interesting to note that his last films were predominantly comedies, whilst his first three films were all dramas. Botha (2012:41-54) discusses De Wet's films and the industry in more detail, but note Botha's statement that light entertainment guaranteed box-office success during the 1950s and 1960s, thus providing a financial incentive for a move to this genre (and the musical) in De Wet's later career (Botha 2012:43).

These films will be referred to in the following discussion when De Wet's collaborations with other role players are discussed.

\section{Pierre de Wet's role in the Afrikaans film industry using SNA}

Social network analysis offers numerous ways to calculate how central an entity is to a network, including degree centrality, closeness centrality, betweenness centrality and eigenvector centrality (Senekal 2013a:677-678). All these centrality calculations measure the importance of an entity in a different way, calculating which entities most often play bridging roles (betweenness centrality), which ones are closest to most other entities in terms of connections (closeness centrality) and so on. Of particular importance in this article is the degree centrality calculation: this measures the number of direct connections an entity has and is an indication of how active an entity is in a network (Senekal 2013a:677). Note however that degree centrality is not in itself necessarily a measure of influence, nor is it necessarily an indication that an entity functions in the centre of a networkthe latter is discussed later in this article. In the network under consideration here, degree centrality is however an indication of how active different kinds of entities were in establishing the Afrikaans film industry.

In the first half-century of Afrikaans film, the companies and people with the highest degree centralities, meaning those who were the most active entities in the film industry network, are shown in Table 1.

This means that Pierre de Wet worked on the largest number of films, Jamie Uys on the second largest number, and so

TABLE 1: Degree centralities of companies and people.

\begin{tabular}{llll}
\hline Company & $\begin{array}{l}\text { Degree } \\
\text { centrality }\end{array}$ & Person & $\begin{array}{l}\text { Degree } \\
\text { centrality }\end{array}$ \\
\hline African Film Productions & 18 & Pierre de Wet & 18 \\
$\begin{array}{l}\text { South African Screen Productions } \\
\text { Jamie Uys Film }\end{array}$ & 12 & Jamie Uys & 11 \\
$\begin{array}{l}\text { Productions } \\
\text { Irene Film Production }\end{array}$ & 9 & Gerald Ehrlich & 10 \\
Utolo & 4 & John C. Brown & 10 \\
Carfo & 3 & Peter Grosset & 10 \\
Swan Films & 3 & Peter Lang & 6 \\
Raath Films & 1 & Emil Nofal & 6 \\
Film Production Facilities & 1 & Vernon Whitten & 6 \\
Debbo-Behrman & 1 & Gordon Vorster & 6 \\
\hline
\end{tabular}

on, whilst African Film Production was involved with the largest number of films, South African Screen Productions was involved with the second largest number of films, and so on. The significance of the above is that involvement in a large number of films creates the opportunity to learn from experience, both for individuals and companies. A director will in all likelihood learn more about his craft as his career progresses; thus, being involved in a large number of films creates a number of opportunities to learn from experience.

These are the most active people and production companies in this period, but of course it is also important to consider people's roles in terms of whether they were directors, producers, writers, editors, cinematographers or music composers. The directors with the highest degree centralities in this period are shown in Table 2.

This means that Pierre de Wet directed the largest number of films in this period, Jamie Uys the second most, and so on. ${ }^{3}$ Table 3 gives the degree centralities of the most active writers, producers, cinematographers, film editors and music composers in this period, organised from high to low degree centralities (note that rows and columns do not indicate collaborations amongst the people named).

Table 3 shows the most prolific contributors to Afrikaans films in this period, with their respective degree centralities being the number of films they worked on as producers, composers and so on. De Wet worked with most of these role players, as the following discussion will show.

De Wet's main collaborators were Gerald Ehrlich (on eight films), John C. Brown (six films), Peter Grosset (five films), Peter Lang (five films), Jan Pohl (four films), Jan Perold (three films), Frank Dixon (three films) and Taffy Kikillus, Joseph Albrecht, Hyman Kirstein and Dennis Gurney (two films each). De Wet worked very closely with the most prolific role players during this time; for example, the sociograms in Figure 1, Figure 2 and Figure 3 show his relationships with John C. Brown, Gerald Ehrlich and Jan Pohl (the label '2 relationships' indicates that a person worked on a film in more than one role, for example Pierre de Wet wrote and directed ' $n$ Plan is ' $n$ boerdery).

TABLE 2: Degree centralities of directors.

\begin{tabular}{ll}
\hline Director & Degree centrality \\
\hline Pierre de Wet & 17 \\
Jamie Uys & 8 \\
Gordon Vorster & 5 \\
Al Debbo & 4 \\
Joseph Albrecht & 3 \\
Kappie Botha & 3 \\
Emil Nofal & 3 \\
Bladon Peake & 2 \\
\hline
\end{tabular}

3. In this instance SNA allows one to explore the database more easily but degree con centrality could have been replaced with a simple count of the number of films people were involved in in different roles (although this would be unnecessarily long-winded, given the size of the database, which consists of 812 role players and 1459 relationships). Moreover, in the interest of consistency with the theoretica paradigm and findings later in this article, I use degree centrality here. 
TABLE 3: Degree centralities of people in different roles.

\begin{tabular}{|c|c|c|c|c|c|c|c|c|c|}
\hline Writer & $\begin{array}{l}\text { Degree } \\
\text { centrality }\end{array}$ & Producer & $\begin{array}{l}\text { Degree } \\
\text { centrality }\end{array}$ & Cinematographer & $\begin{array}{l}\text { Degree } \\
\text { centrality }\end{array}$ & Editor & Degree centrality & Composer & Degree centrality \\
\hline Pierre de Wet & 15 & Jamie Uys & 7 & John C. Brown & 10 & $\begin{array}{l}\text { Gerald } \\
\text { Ehrlich }\end{array}$ & 10 & Jan Pohl & 5 \\
\hline Jamie Uys & 9 & Al Debbo & 3 & Peter Lang & 6 & $\begin{array}{l}\text { Peter } \\
\text { Grosset }\end{array}$ & 10 & $\begin{array}{l}\text { Anton de } \\
\text { Waal }\end{array}$ & 4 \\
\hline Gordon Vorster & 6 & Joseph Albrecht & 1 & Vernon Whitten & 6 & $\begin{array}{l}\text { Dennis } \\
\text { Gurney }\end{array}$ & 3 & $\begin{array}{l}\text { Taffy } \\
\text { Kikillus }\end{array}$ & 4 \\
\hline Emil Nofal & 5 & Emil Nofal & 2 & Judex C. Viljoen & 5 & $\begin{array}{l}\text { Harry } \\
\text { Hughes }\end{array}$ & 3 & $\begin{array}{l}\text { Nico } \\
\text { Carstens }\end{array}$ & 2 \\
\hline Jan Perold & 3 & Jannie Raath & 1 & David Millen & 4 & $\begin{array}{l}\text { Elmo de } \\
\text { Witt }\end{array}$ & 2 & Sam Sklair & 2 \\
\hline
\end{tabular}

Whilst De Wet directed six out of the ten films John C. Brown did the cinematography on from this period, he directed eight out of the ten films Ehrlich edited and four out of the five films for which Jan Pohl composed music. The above thus shows that Pierre de Wet not only worked with the most productive cinematographers, editors and composers, but also he worked with them on the majority of their films, contributing directly to them being the most prolific persons in their respective roles. In other words: De Wet created the opportunity for these role players to work on films, allowing them to gain experience in the film industry.

De Wet obviously worked with a wide variety of role players, not only with the most prolific. In the sociogram in Figure 4, his relationship as film director with film editors is represented.

Here it can be seen that he worked with Gerald Ehrlich on numerous films: Geboortegrond (1946), Simon Beyers (1947), Die kaskenades van Dr. Kwak (1948), Kom saam vanaand! (1949), Hier's ons weer (1950), Altyd in my drome (1952), 'n Plan is ' $n$ boerdery (1954) and Matieland! (1955). He also worked extensively with Peter Grossett on Dis lekker om te lewe (1957), Fratse in die vloot (1958), Nooi van my hart (1959) and En die vonke spat (1961). He also worked with Dennis Gurney on both Alles sal regkom (1951) and Vadertjie langbeen (1955), whilst Hyman Kirstein worked on the latter film as editor as well. On Pinkie se erfenis (1946), De Wet worked with F. Wellbach and J.W. van F. Louw. Remember that the above collaboration network only focuses on the film editors he worked with. Of course, his collaborations with cinematographers were as numerous, as the sociogram in Figure 5 shows.

In Figure 5, it can be seen that he worked extensively with Peter Lang, John C. Brown, and Frank Dixon, whilst also working with David Millen ('n Plan is ' $n$ boerdery), Hans Wagner (En die vonke spat), and D.P. Muller (Pinkie se erfenis).

Another facet of his collaborations is the music composers who contributed to his films, as can be seen in the sociogram in Figure 6.

Here it can be seen that De Wet worked extensively with Jan Pohl, whilst also working with Taffy Kikillus (Fratse in die vloot and ' $n$ Plan is ' $n$ boerdery), Nico Carstens and Anton de Waal (both also on ' $n$ Plan is ' $n$ boerdery).

Pierre de Wet's overall position in the Afrikaans film industry network is however influenced by more than who he worked with (in this case second-degree connections): their connections (third-degree connections, i.e. films De Wet's collaborators worked on) are also important. Consider for example the connections of composers De Wet worked with: Anton de Waal, Jan Pohl and Nico Carstens were particularly prolific composers. Jan Pohl also composed music for Huis op Horings and Man in die Donker, whilst Anton de Waal composed music for Daar doer in die bosveld and Jy's lieflik vanaand (with George Esaul and Louis Combrinck). De Waal also teamed up with Ernst van Rooyen and Nico Carstens for Geld soos bossies, whilst working with Carstens on Stadig oor die klippe, whereas Carstens himself composed music for Die wonderwêreld van Kammie Kamfer. Geld soos Bossies and Daar doer in die bosveld are of course Jamie Uys films, and thus De Waal and Carstens provide structural bridges between the works of Pierre de Wet and Jamie Uys. Taffy Kikillus also composed on Gevaarlike spel and Donker AfrikaAl Debbo and David Millen films respectively. As such, Kikillus provides a link between Pierre de Wet and these two important filmmakers. Kikillus's second-degree connections are given in Figure 7.

As can be seen in Figure 7, Taffy Kikillus thus worked on four films: Donker Afrika, Gevaarlike spel and the two with Pierre de Wet: ' $n$ Plan is ' $n$ boerdery and Fratse in die vloot. Consequently, Kikillus, like De Waal and Carstens, forms a bridge between these filmmakers.

Granovetter (1983) proposed that weak ties between members belonging to different groups are of special structural importance, for they provide contacts that would otherwise not have existed. He formulated his argument as follows:

The overall social structural picture suggested by this argument can be seen by considering the situation of some arbitrarily selected individual - call him or her 'Ego.' Ego will have a collection of close-knit friends, most of whom are in touch with one another - a densely knit 'clump' of social structure. In addition, Ego will have a collection of acquaintances, few of whom know one another. Each of these acquaintances, however, is likely to have close friends in his or her own right and therefore to be enmeshed in a closely knit clump of social structure, but one different from Ego's. The weak tie between Ego and his or her acquaintance, therefore, becomes not merely a trivial acquaintance tie, but rather a crucial bridge between the two densely knit clumps of close friends. To the extent that the assertion of the previous paragraph is correct, these clumps would not, in fact, be connected to one another at all were it not for the existence of weak ties. (Granovetter 1983:203) 


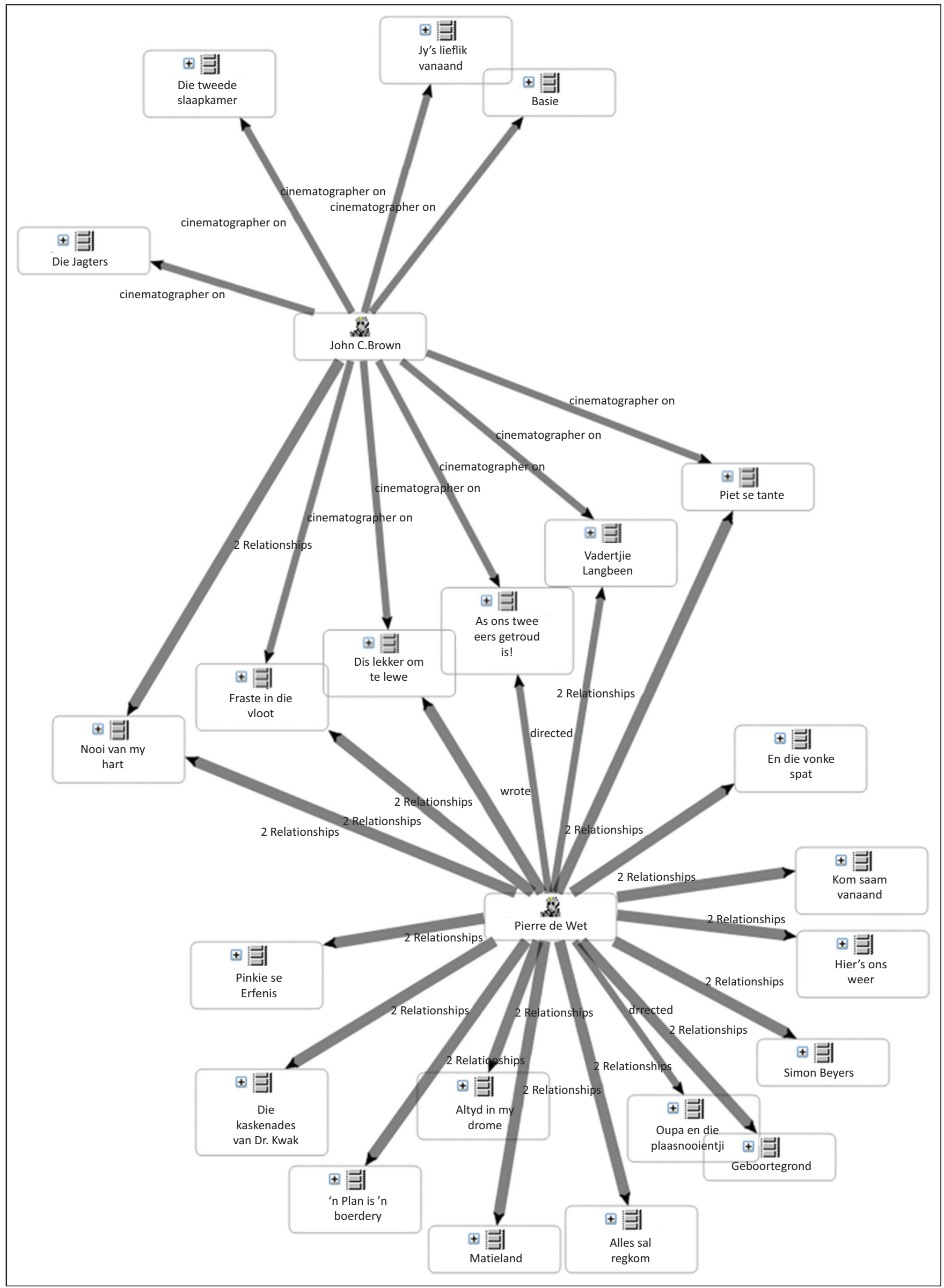

FIGURE 1: Pierre de Wet's collaborations with John C. Brown. 


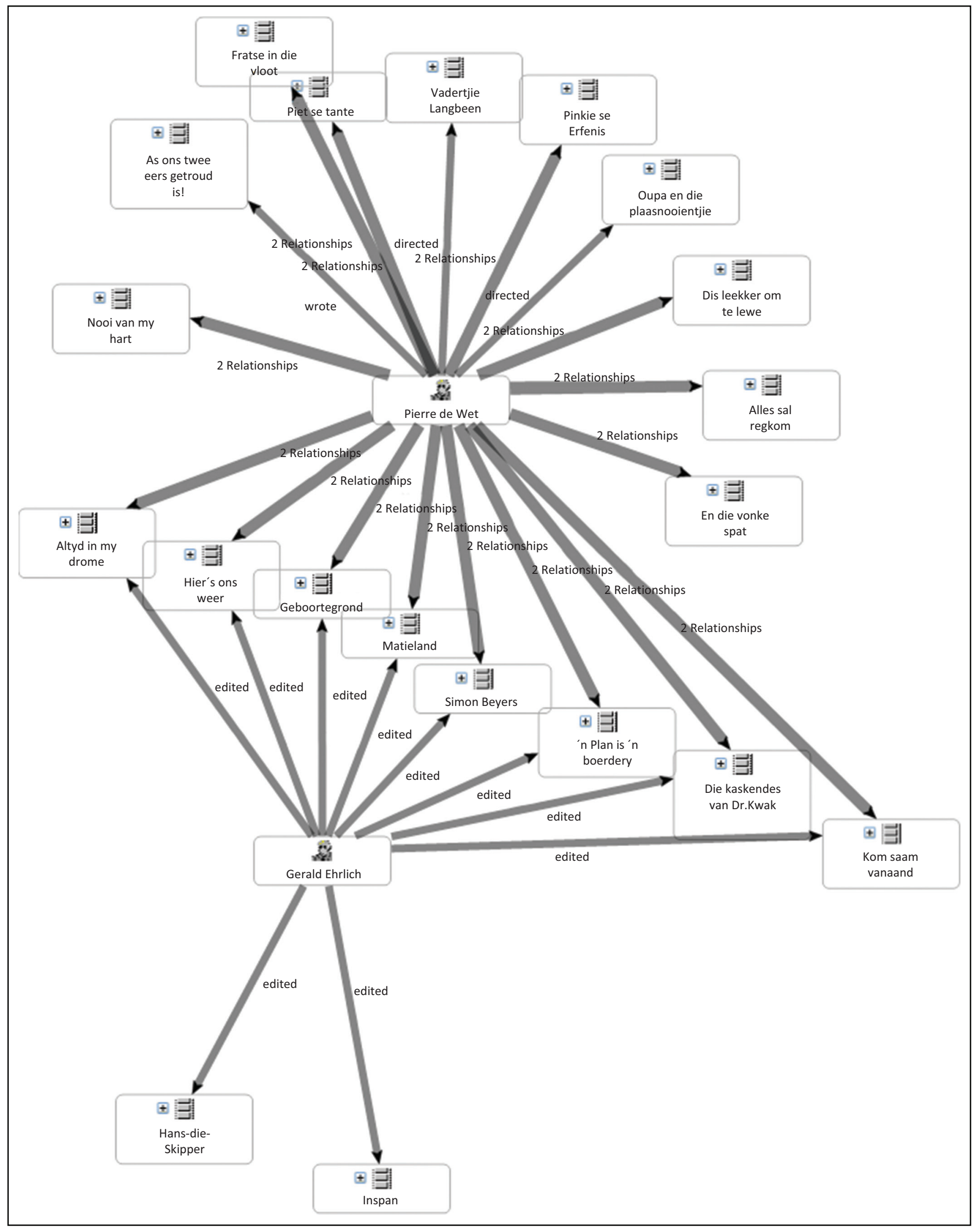

FIGURE 2: Pierre de Wet's collaborations with Gerald Ehrlich. 


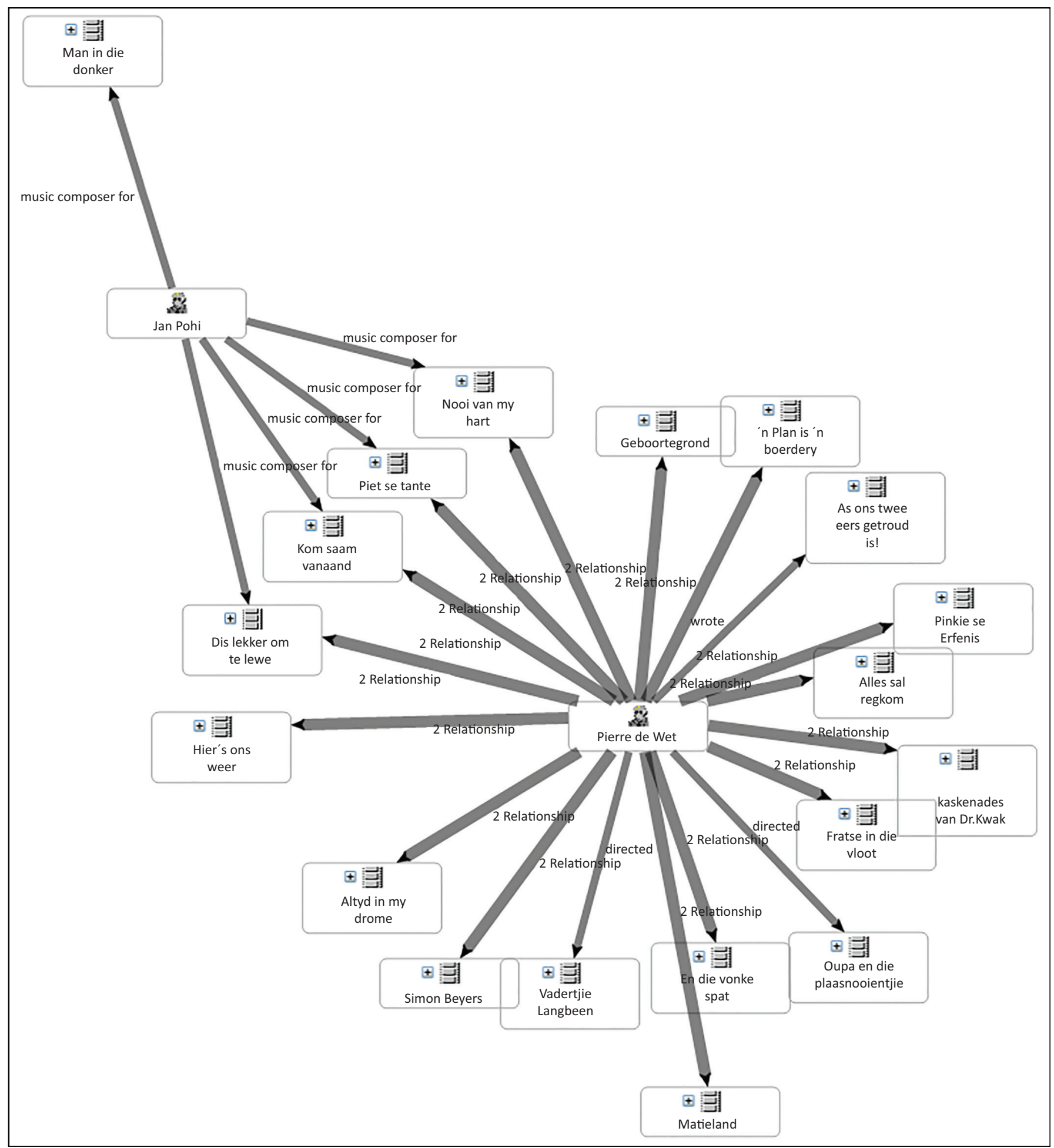

FIGURE 3: Pierre de Wet's collaborations with Jan Pohl.

In this case, the ties facilitated by composers thus provide coherence to the Afrikaans film industry, meaning that they provide connections that would otherwise not have existed. By using such well-connected composers, Pierre de Wet thereby contributed to the coherence of the industry as a whole, which creates the potential for information to flow in the network. Music composers are however only one example of De Wet's collaborators lending coherence to the network: as composers form bridges between films, so too do co-directors and producers connect films, as well as cinematographers and film editors. Considering Pierre de Wet's third-degree connections (the films contributed to by people who collaborated on films with De Wet), it is clear that De Wet worked with a large number of well-connected collaborators (see Figure 8).

Pierre de Wet thus worked with David Millen on ' $n$ Plan is ' $n$ boerdery (where Millen was the cinematographer), whilst Millen also worked as cinematographer on Donker Afrika, Die banneling, Hans-die-skipper and inspan. Millen also wrote 


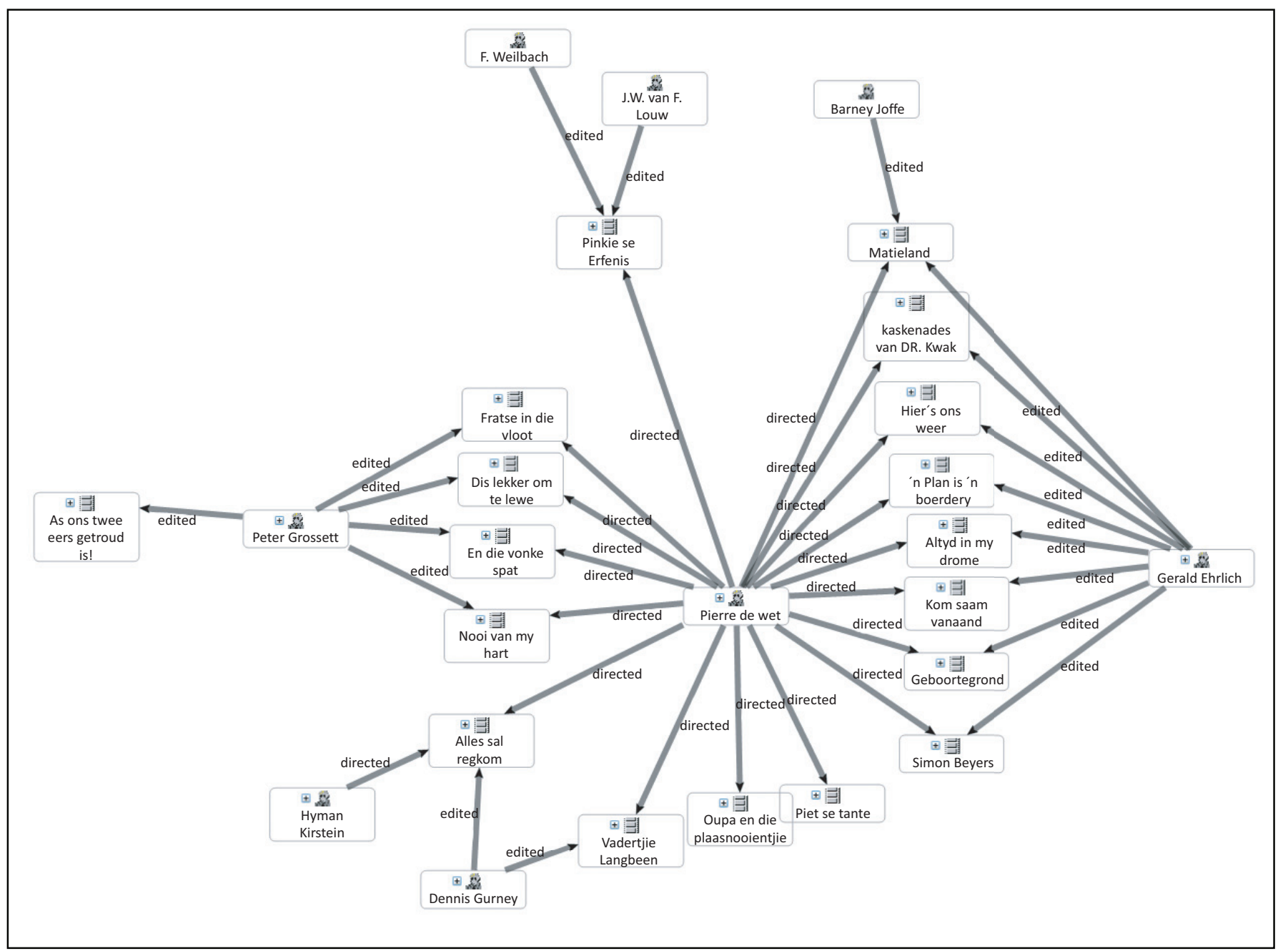

FIGURE 4: Pierre de Wet's relationships as film director with film editors.

Stropers van die laeveld and Met moed, durf en bloed (both films he also directed) and directed Die Voortrekkers, Suster Theresa and Majuba. Millen's second-degree links (which thus form part of Pierre de Wet's third-degree connections) also include collaborations with Bladon Peake, Gordon Vorster, Emil Nofal, Hyman Kirstein and Gilbert Gibson (who wrote the music for Dirkie), making him particularly well-connected in the film industry (Emil Nofal was for instance a close collaborator of Jamie Uys). Yet Millen is only one of Pierre de Wet's collaborators: Jan Pohl, Peter Grosset, John C. Brown and others provide similar connections to the larger Afrikaans film industry. The importance of working with such prolific role players is that it maximises the opportunity for information to flow in the network, both by possibly transferring techniques and insights to De Wet, allowing him to learn more about filmmaking and by transferring his experience throughout the industry, which could allow him to teach - a bi-directional flow of information. His collaborations with prolific role players maximises this potential, as it brings people who come in contact with him into contact with the most other role players. With reference to communication networks in organisations, Zhu, Watts and Chen (2010) write:

Organizations find it useful to know which of their members have high degree centrality, since these members are likely to be able to successfully diffuse information throughout their networks. It is often not desirable to transfer members with high degree centrality out of their networks, since this is likely to disrupt knowledge movement. (p. 152)

The precise details of these collaborations, as well as in which direction the information flows, can be the subject of future research. Note also that this does not in itself make De Wet influential: his connections to role players who worked on a large number of films create the opportunity for information to flow in the network, but a more detailed analysis would be required to establish who influenced whom.

When Pierre de Wet's fourth-degree connections are considered, which means those who collaborated on films with people who collaborated on films on which Pierre de Wet worked, the network is vast and intricate, as shown in Figure 9 .

The periphery of this four-degree network perhaps illustrates the extent of Pierre de Wet's connections best: at the top are Vincent G. Cox, Gert van den Berg, Joan Kenney and Mimosa Films - a link provided through Nico Carstens, who composed the music for De Wet's 


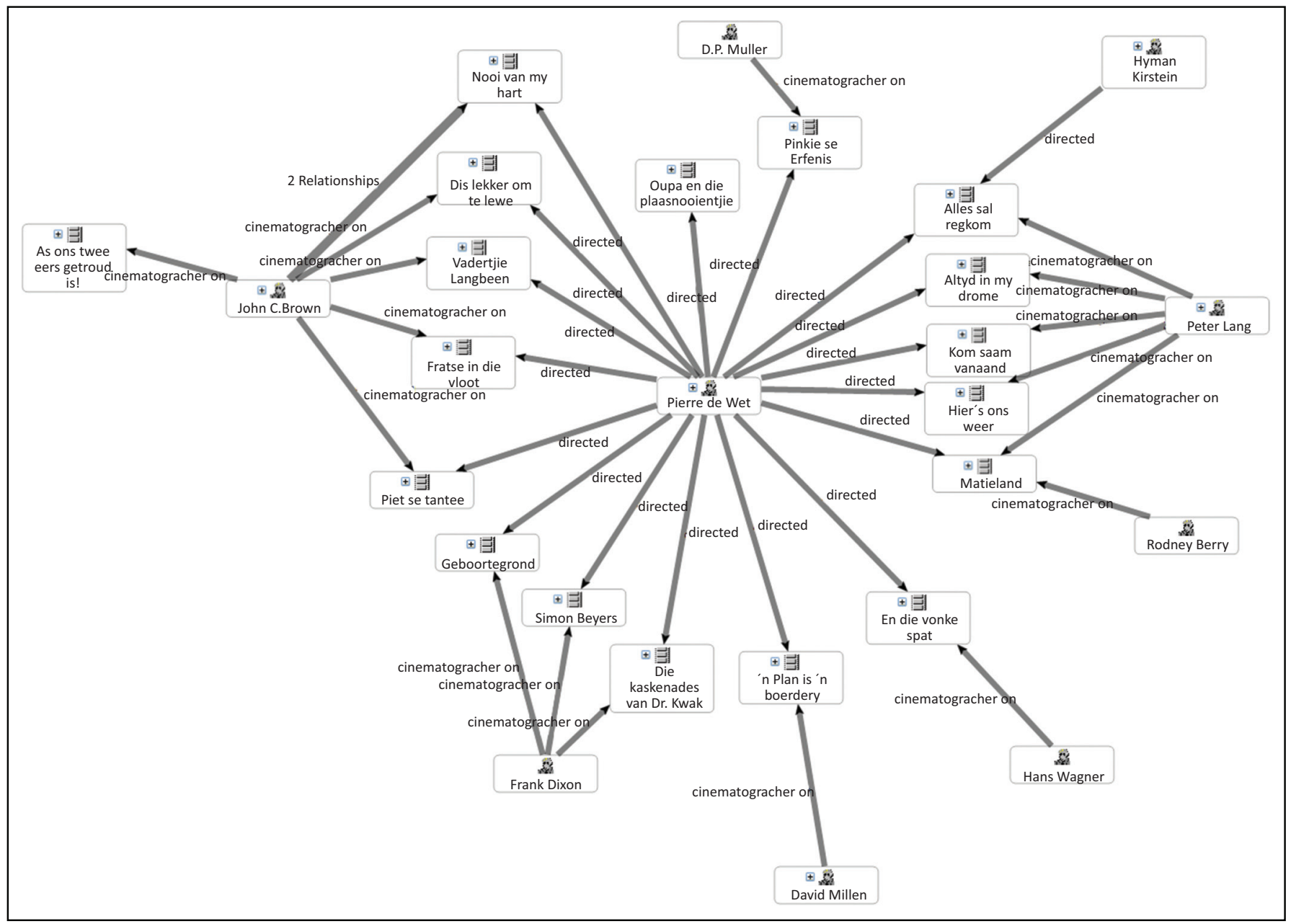

FIGURE 5: Pierre de Wet's collaborations with cinematographers.

film ' $n$ Plan is ' $n$ boerdery and who also composed music for the first Mimosa Films production, Die wonderwêreld van Kammie Kamfer (an alternative link is provided though Taffy Kikillus's composition for both Fratse in die vloot and the Al Debbo film Gevaarlike spel). On the right, Pierre de Wet is linked as far as Donald Swanson, who co-wrote Die Voortrekkers with Oliver Ransford. This link is provided through David Millen's cinematography on ' $n$ Plan is ' $n$ boerdery. On the bottom, Pierre de Wet is even linked to C.J. Langenhoven, a link provided through Pinkie se erfenis, which was produced by Utolo, the company that also produced Donker spore, which was written by Langenhoven.

When looking at the position of Pierre de Wet in the Afrikaans film industry, four-degree links provide a good context, but a better context would be considering him within the context of the entire industry from 1916 to 2013. This is the largest context that can be considered using this data set (812 role players and 1459 relationships) and even here, short paths abound. His position in the entire Afrikaans film network is indicated with the red square in Figure 10.

Whilst this position is not in the absolute centre of the network, remember that De Wet made his last film in 1962.
In comparison, Katinka Heyns is indicated with the circle, Darrell Roodt with the diamond and Jamie Uys with the star. Whilst Uys is more central in the entire network, De Wet is central to his cluster and this cluster is generally composed of older films. De Wet may not be at the centre of the entire Afrikaans film industry network, like Jamie Uys, but when only films are considered that were released in the first 50 years of the Afrikaans film industry, he is at the centre, as Figure 11 shows.

In Figure 11, a sociogram of the entire film industry network, a force-directed layout algorithm was used to position entities. Force-directed layout algorithms consider the network as a physical system in which the ties between entities are seen as forces of attraction and repulsion (see Di Battista et al. 1994:242; Fruchterman \& Reingold 1991:1131; Merico, Gfeller \& Bader 2009:922). The position of an entity in the centre of a network, or even in the centre of a cluster, thus indicates that other entities are literally pulled towards that entity, whilst taking every connection in the entire network into account. A central position is then the result of connections of connections of connections of connections and is one of the best ways to identify which entities function at the core of a network (unlike degree centrality, which does not necessarily indicate a position at the core and only considers direct connections). 


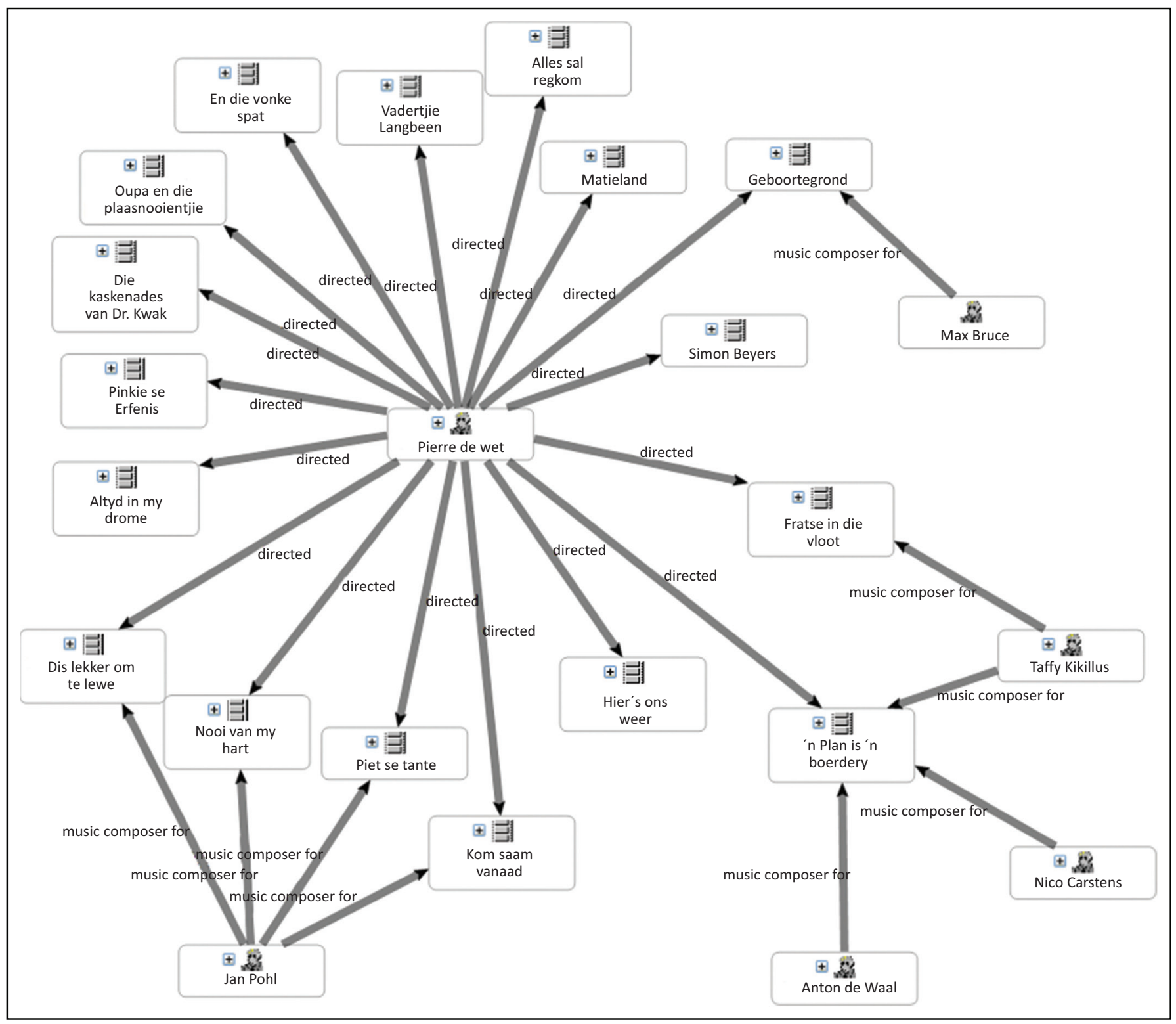

FIGURE 6: Pierre de Wet's collaborations with music composers.

Kobourov (2013:397) writes that 'in traditional drawings in $R^{2}$ [two-dimensional Euclidean space] there is an implicit assumption that nodes in the center are important, while nodes on the periphery are less important'. It follows that force-directed layouts of systems can identify the important entities in a system. In the case of for instance the Afrikaans poetry network, Senekal (2013b) illustrates that this algorithm positions figures who are considered at the heart of the Afrikaans poetry canon (such as Antjie Krog) in the centre, whilst placing marginal figures (such as Fokofpolisiekar) on the periphery, thereby illustrating the practical applicability of this algorithm in determining whether or not an entity is central or peripheral to a cultural system. Similarly, Jamie Uys is positioned at the core of this industry, as illustrated and discussed in Senekal and Stemmet (2014:12-13). Pierre de Wet can thus also be said to be central to the Afrikaans film industry, as positioned with the use of a force-directed algorithm.

\section{Conclusion}

Pierre de Wet is often seen as the father of the Afrikaans film industry and, as this article has shown, he has a large number of ties to people who were also involved with a large number of films during the industry's beginning years. Although only a few examples were used to discuss De Wet's connections in the industry, it was shown how closely he was involved with some of the most productive role players in the industry, meaning people who were involved in a large number of films. His role at the centre of the industry (when only considering the first 50 years of the industry) as indicated using a force-directed layout algorithm - is dependent upon his connections to the rest of the industry, and shows how he concentrated action around him through being not only the person who directed the largest number of films, but also by collaborating with some of the most prolific role players in the industry. The significance of De Wet's high degree centrality, and the high degree centralities of many of 


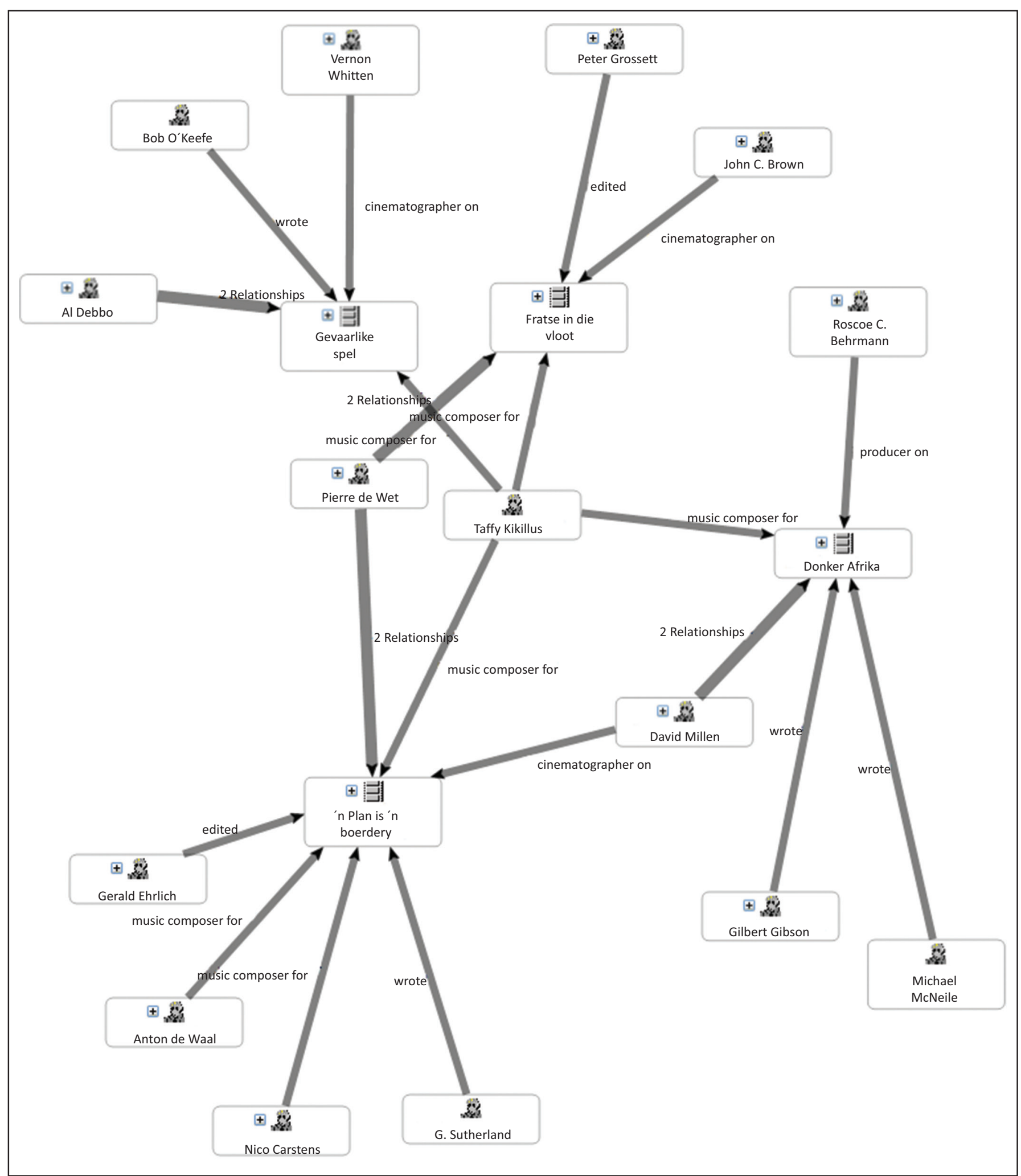

FIGURE 7: Taffy Kikillus's second-degree connections.

his collaborators, is that it allowed for information flow in the film industry, both by role players accumulating experience through working on a large number of films and by these role players being able to transfer experience through coming into contact with a large number of other role players who also have a large number of connections. The nature of the information flow could be investigated in future studies, for example investigating who learnt which skills from De Wet and who taught De Wet about filmmaking.

The article also demonstrated SNA's potential as an investigative tool for identifying and describing an entity's context: connections are paramount in any cultural system and through SNA even distant connections can be identified 


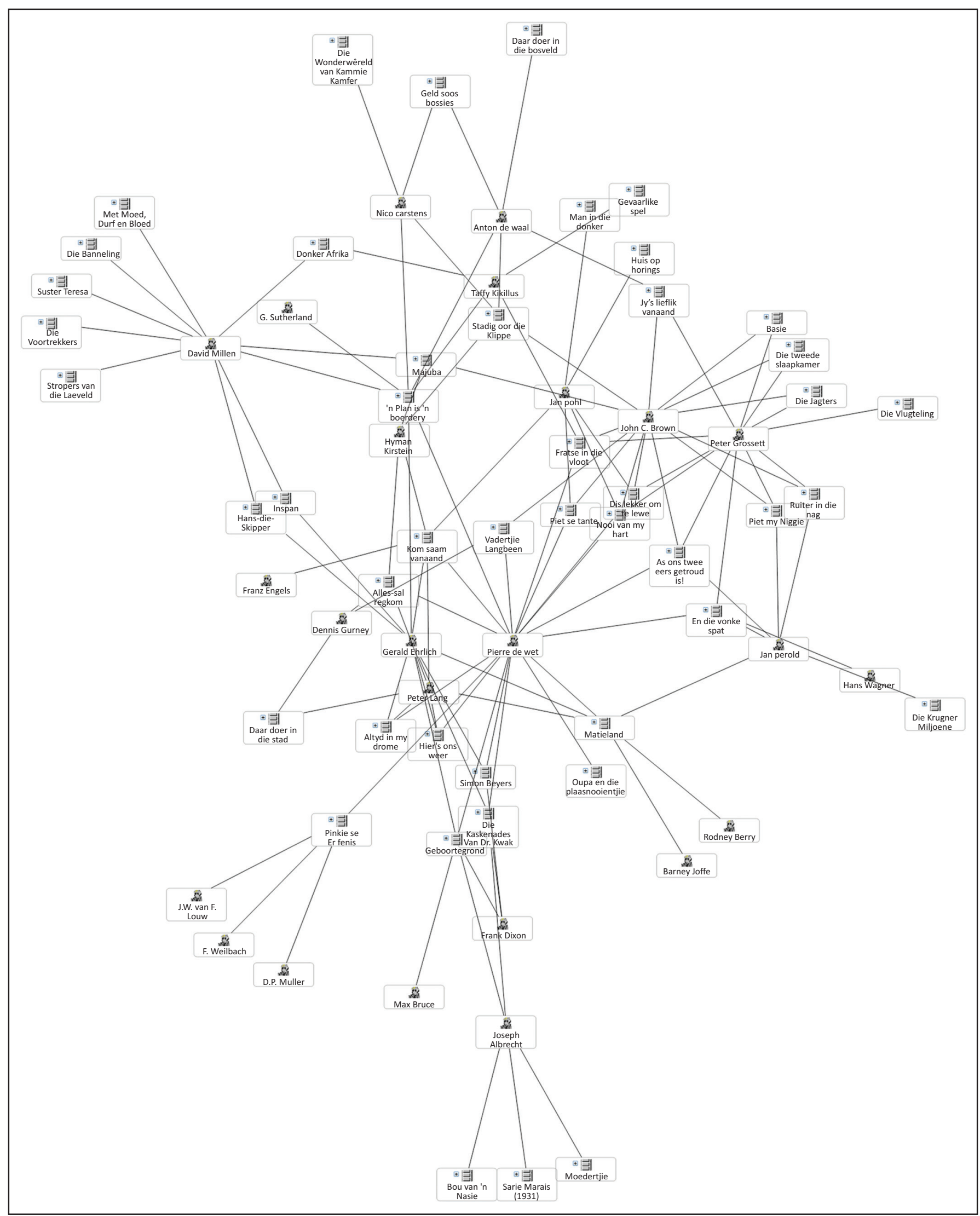

FIGURE 8: Pierre De Wet's third-degree connections.

and explored. Similar studies could be done to explore the roles of other filmmakers and companies in the entire network, as has been done by Senekal and Stemmet (2014) with regard to Jamie Uys, and, of course, the entire South African film industry could be investigated, not simply the Afrikaans film industry. 


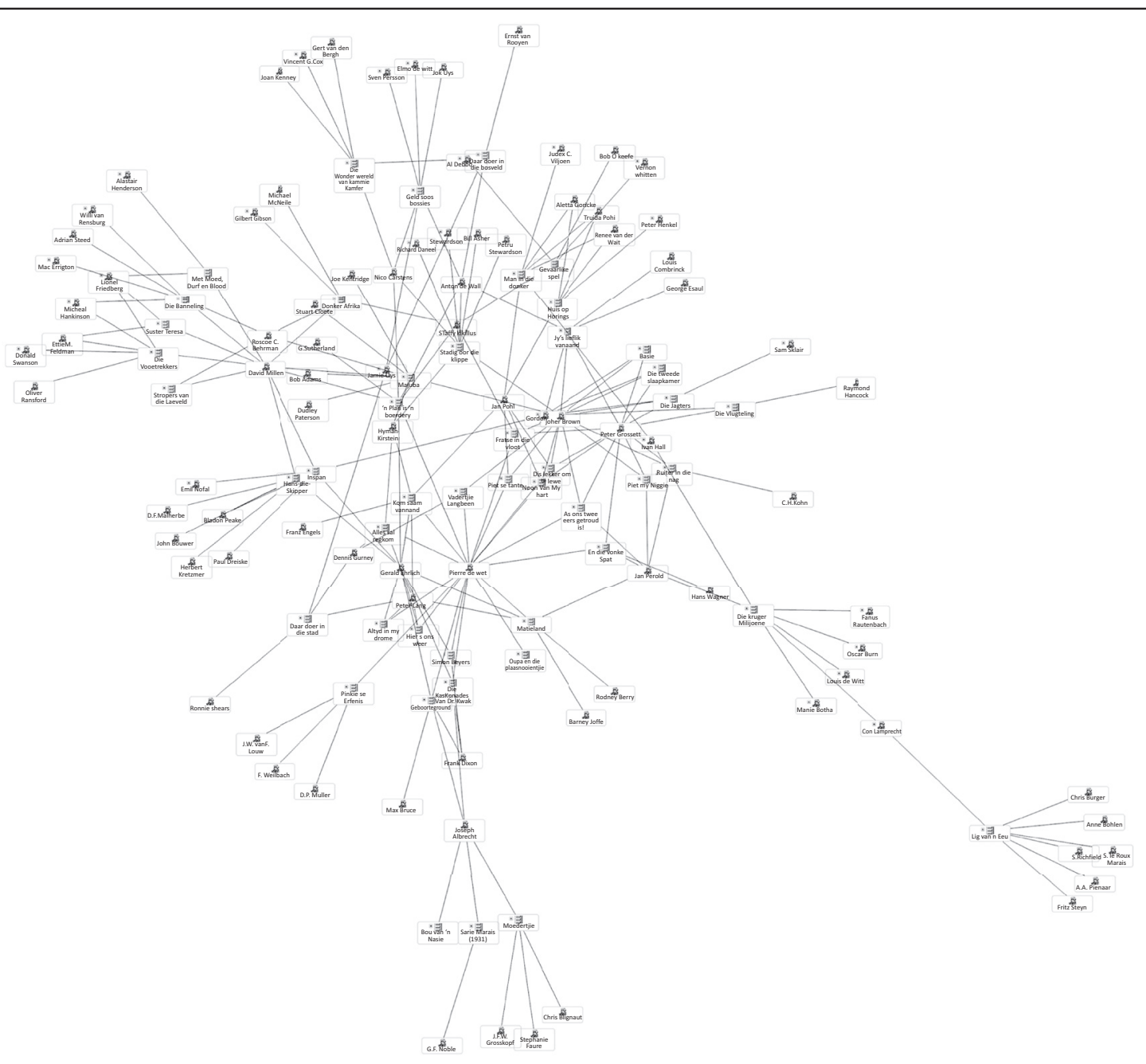

FIGURE 9: Pierre de Wet's fourth-degree connections.

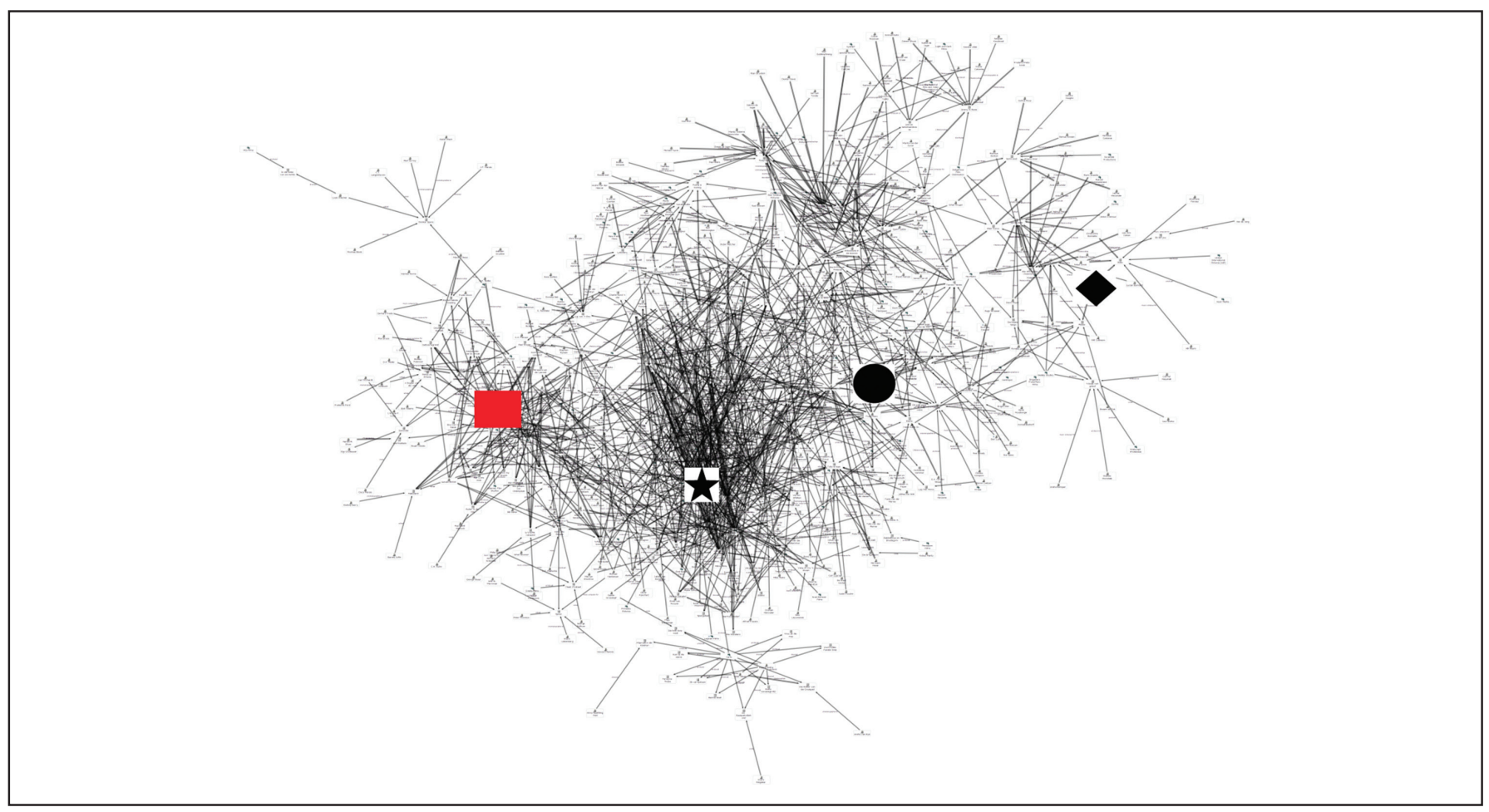

FIGURE 10: Pierre de Wet's position in the entire Afrikaans film network. 


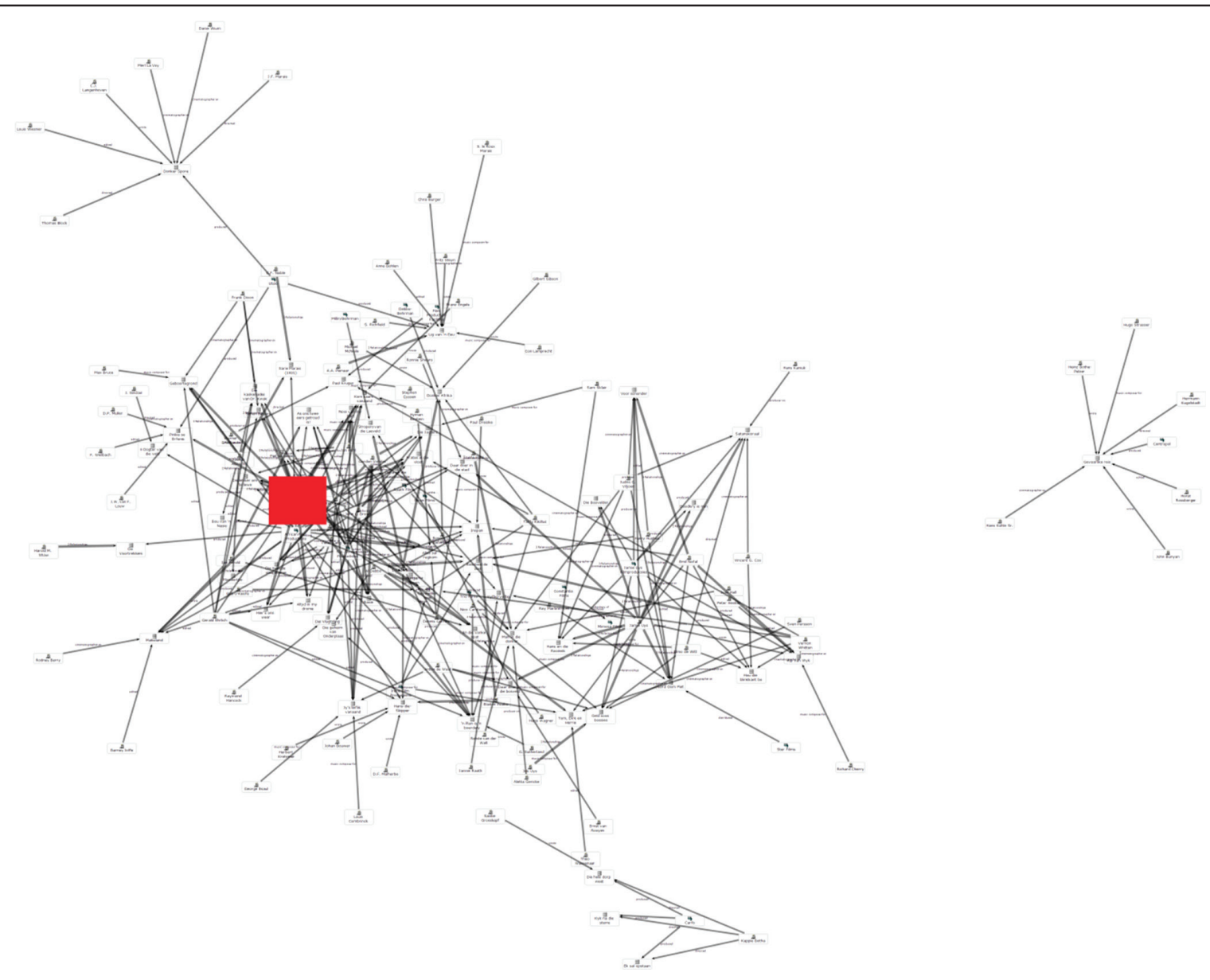

FIGURE 11: Pierre de Wet's position in the first 50 years of the Afrikaans film industry network.

\section{Acknowledgements}

\section{Competing interests}

I declare that I have no financial or personal relationship(s) that may have inappropriately influenced me in writing this article.

\section{Bibliography}

Barabási, A.-L., 2009, 'Scale-free networks: a decade and beyond', Science 325(5939), 412-413. http://dx.doi.org/10.1126/science.1173299

Blignaut, J. \& Botha, M. (eds.), 1992, Movies, moguls, mavericks: South African cinema 1979-1991, Showdata, Cape Town

Botha, M., 2006a, '110 Years of South African cinema,' Kinema, viewed 16 November 2013, from http://www.kinema.uwaterloo.ca/article.php?id=46\&feature

Botha, M., 2006b, Jans Rautenbach: Dromer baanbreker en auteur, Genugtig!, Melkbosstrand, South Africa.

Botha, M., 2012, South African cinema 1896-2010, Intellect, Bristol.

Brandes, U., Freeman, L.C. \& Wagner, D., 2013, 'Social networks', in R. Tamassia (ed.), Handbook of graph drawing and visualization, pp. 805-840, CRC Press, Boca Raton.

Britz, E., 1990, 'Pierre de Wet was 'n ware pionier', Beeld, 29 June, bl. 3.

Brownlee, J., 2007, 'Complex adaptive systems', CIS Technical Report March, 1-6.

Di Battista, G., Eades, P., Tamassia, R. \& Tollis, I.G., 1994, 'Algorithms for drawing graphs: An annotated bibliography', Computational Geometry 4(5), 235-282. http://dx.doi.org/10.1016/0925-7721(94)00014-X

Fruchterman, T.M.J. \& Reingold, E.M., 1991, 'Graph drawing by force-directed placement', Software: Practice and Experience 21(11), 1129-1164. http://dx.doi. org/10.1002/spe.4380211102

Granovetter, M.S., 1983, 'The strength of weak ties: A network theory revisited' Sociological Theory 1, 203-233. http://dx.doi.org/10.2307/202051

Gutsche, T., 1972, The history and social significance of motion pictures in South Africa, 1895-1940, Howard Timmins, Cape Town.
Hechter, M., 2010, 'Van loerprente tot ' $n$ glansryke teater - só is ou Pretorianers vermaak', Die Bronberger, 26 March, viewed 16 November 2013, from http:// www.bronberger.co.za/index.php?option $=$ com_content\&task $=$ view\&id=742\&Ite mid $=76$

Kobourov, S.G., 2013, 'Force-directed drawing algorithms', in R. Tamassia (ed.), Handbook of graph drawing and visualization, pp. 383-408, CRC Press, Boca Raton.

Le Roux, A. \& Fourie, L., 1982, Filmverlede: Geskiedenis van die Suid-Afrikaanse speelfilm, UNISA, Pretoria.

Merico, D., Gfeller, D. \& Bader, G.D., 2009, 'How to visually interpret biological data using networks', Nature Biotechnology 27(10), 921-924. http://dx.doi. org/10.1038/nbt.1567

Mitchell, M., 2006, 'Complex systems: Network thinking', Artificial Intelligence 170(18), 1194-1212. http://dx.doi.org/10.1016/j.artint.2006.10.002

Senekal, B.A., 2013a, 'Die gebruik van die netwerkteorie binne ' $n$ sisteemteoretiese benadering tot die Afrikaanse letterkunde: 'n Teorie-oorsig', Tydskrif vir Geesteswetenskappe 53(4), 668-682.

Senekal, B.A., 2013b, 'n Bespreking van die Afrikaanse poësienetwerk sedert 2000 viewed 10 May 2013, from http://www.litnet.co.za/Article/n-bespreking-van-dieafrikaanse-posienetwerk-sedert-2000

Senekal, B.A. \& Stemmet, J.-A., 2014, 'The gods must be connected: An investigation of Jamie Uys's connections in the Afrikaans film industry using social network analysis (SNA)', Communicatio 40(1), 1-19. http://dx.doi.org/10.1080/02500167 .2014 .888361

Senekal, J.H., 1987, Literatuuropvattings: 'Wese' en 'waarhede' van 'n nuwe literêre teorie, Universiteit van die Oranje-Vrystaat, Bloemfontein, South Africa.

Tomaselli, K.G., 1988, The cinema of apartheid: Race and class in South African cinema, Smyrna Press, New York.

Van der Westhuizen, C., 2012, 'Vloot-komedie "vader van Afrikaanse rolprent", Rapport, 29 April, besigtig 01 September 2014, by http://www.rapport.co.za/ Suid-Afrika/Nuus/Vloot-komedie-vader-van-Afrikaanse-rolprent-20120428

Viljoen, H., 1986, 'Die Suid-Afrikaanse romansisteem. 'n Vergelykende studie', unpublished PhD thesis, Department of Central Publications, University of the North West, South Africa.

Zhu, B., Watts, S. \& Chen, H., 2010, 'Visualizing social network concepts', Decision Support Systems 49(2), 151-161. http://dx.doi.org/10.1016/j.dss.2010.02.001 